\title{
PENINGKATAN PERAN PTK-PNF DALAM PEMBELAJARAN BERBASIS INFORMASI KOMPUTER DAN TEKNOLOGI
}

\begin{abstract}
Rasid $^{*}$
Abstract

Under an assumption that in the present days information and communication technology plays an important role in teaching and learning process, this article discusses how ICT can support the attainment of learning achievement. Based on the empirical studies, it recommends the educators and the supporting staff of non-formal education to improve their skills in using ICT in non-formal education and apply them in the instructional activities.
\end{abstract}

Keywords: technology function, information and communication technology, learning.

\section{PENDAHULUAN}

Perkembangan kemajuan ilmu pengetahuan dan teknologi sangat berpengaruh pada dunia pendidikan, khususnya dalam pelaksanaan program pembelajaran. Pemanfaatan hasil teknologi guna mempercepat proses pemahaman peserta didik hanya sebagai sarana.

Teknologi komputer dikembangkan pada tahun 1950-an sebagai kreasi besar tahun itu dengan tabungtabung vakum dan bermil-mil kabel memenuhi ruangan besar. Tahun 1975 muncul hasil rekayasa komputer besar menjadi mikrokomputer dan selanjutnya ditemukan mikroprosesor, yaitu sebuah chip silikon tipis yang di dalamnya berisi seluruh kemampuan pemrosesan informasi dari ruang sirkuit komputer orisinal sampai dengan keadaan kemajuan teknologi sekarang ini (Sudjana dan Rivai, 2003:136).

Penggunaan teknologi sebagai sarana pembelajaran sangat strategis untuk mempercepat proses perubahan siswa. Dampak pemanfaatan hasil teknologi dalam proses pembelajaran berbentuk nilai Munir dalam Ali, dkk. (2007:1351) mengatakan kemajuan Teknologi Informasi (TI) dapat mengantarkan dunia maya ke hadapan kita. Paradigma pendidikan yang semula berbasis tradisional dengan mengandalkan tatap muka dengan sentuhan $\mathrm{TI}$ akan beralih menjadi pendidikan yang tidak dibatasi oleh ruang dan waktu.

Pembelajaran pada hakikatnya mempersiapkan peserta didik untuk dapat menampilkan tingkah laku

* Mahasiswa SPS Universitas Pendidikan Indonesia hasil belajar dalam kondisi nyata atau untuk memecahkan masalah dalam kehidupannya.

Dalam melengkapi sarana dan prasarana pendidikan terutama yang berkaitan dengan TI sebagai media pendidikan maka kontribusi material dari tripartisipasi pendidikan, yaitu orang tua siswa, masyarakat, dan pemerintah perlu digalakkan. Abdulhak dalam Ali, dkk. (2007:523) mengemukakan secara konsep dan praktik, program pembelajaran memerlukan perhatian semua pihak yang memiliki keterkaitan tidak hanya diserahkan kepada pendidik saja.

Menurut Resnick dalam Wahid (2007:68) ada tiga hal penting yang harus dipikirkan terkait modernisasi pendidikan, yakni (1) bagaimana kita belajar (how people learn), (2) apa yang kita pelajari (what people learn), dan (3) kapan dan di mana kita belajar (where and when people learn). Dengan mencermati tiga faktor tersebut potensi TI yang bisa dimanfaatkan dapat menunjang modernisasi pendidikan bangsa positif dalam mempercepat pemahaman siswa terhadap substansi mata pelajaran.

Fungsi teknologi sebagai media pembelajaran dalam mentransmisikan dan mentransformasikan pengetahuan, keterampilan, dan perubahan sikap kepada siswa memerlukan ketersediaan sarana dan prasarana pendukung, sumber daya pendidik yang berkualitas, dan menjunjung nilai moral.

Pertanyaan bagaimana kita belajar terkait dengan metode atau model pembelajaran, cara berinteraksi antara guru dengan siswa. Saat ini terjadi perubahan paradigma pembelajaran terkait dengan ketergantungan 
terhadap guru dan peran guru dalam proses pembelajaran. Apakah yang kita pelajari sesuai dengan kurikulum yang telah dirancang untuk mempersiapkan siswa hidup dan bekerja pada masa yang akan datang serta kapan dan di mana belajar dilakukan; apakah harus dilakukan di ruang kelas dalam waktu tertentu atau tidak terbatas ruang dan waktu.

Budiningsih (2005:86) menyatakan proses pengolahan informasi dalam ingatan dimulai dari proses penyandian informasi (encoding), diikuti dengan penyampaian informasi (storage), dan diakhiri dengan penyimpanan informasi yang telah disimpan dalam ingatan (retrieval).

Selain itu, Bacon dalam Ali, dkk. (2007:323) berpandangan bahwa pengembangan ilmu pengetahuan tidak dapat dicapai kecuali melalui eksperimen. Metode induktif yang dikembangkan merupakan dasar untuk melakukan observasi dalam eksperimen terutama dalam upaya merumuskan prinsip-prinsip, hukumhukum, dan teori-teori ilmu pengetahuan sebagaimana dalam penelitian ilmiah modern. Metode induktif Bacon mengandung dua unsur utama, yaitu menggunakan logika dan pengumpulan data yang diperoleh melalui observasi. Logika digunakan dalam menarik kesimpulan sedangkan dasar penarikan kesimpulan itu adalah data hasil observasi. Metode ini dapat dipandang sebagai tunas dalam penelitian ilmiah modern.

Berdasarkan uraian mengenai pentingnya pembelajaran Pendidikan Nonformal (PNF) melalui jaringan informasi komputer dan teknologi maka satuan PNF perlu mempersiapkan diri baik dari segi sarana dan prasarana maupun kualitas Sumber Daya Manusia (SDM).

\section{PEMBAHASAN}

\section{Peningkatan Peran Pendidik dan Tenaga Kependidikan Pendidikan Nonformal (PTK-PNF) dalam Pembelajaran Berbasis Informasi Komputer dan Teknologi}

Mencermati fenomena kemajuan TI baik yang langsung berkenaan sebagai media pembelajaran di kelas seperti komputer, Liquid Crystal Display (LCD) maupun yang tidak langsung berperan sebagai media pembelajaran di kelas, seperti handycam dan digital camera.

Pembelajaran yang menggunakan TI akan sangat berbeda dengan pembelajaran tanpa menggunakan media komputer, baik dari segi strategi maupun metode. Oleh karena itu, warga belajar perlu dibimbing secara kontruktivisme dalam implementasi pembelajaran. Ishak (2007:528) menyatakan program pembelajaran pada hakikatnya ditujukan untuk kepentingan efisiensi pembelajaran sehingga setiap penyelenggaraan pembelajaran perlu didasarkan pada prinsip-prinsip pembelajaran yang tepat.

Selain itu, dampak penguasaan TI bagi peserta didik akan dapat menimbulkan resiko besar jika siswa yang bersangkutan tidak dibekali dengan pesan-pesan moral agama, budaya, dan etika keilmuan yang perlu dijunjung tinggi sebagai wujud penegakan moral dan akhlak serta penegakan kejujuran ilmiah. Kecenderungan menggunakan TI bagi seseorang dibayangi oleh rasa takut akan rusaknya alat tersebut. Budaya takut dan merasa asing atas berbagai alat elektronik tersebut menyebabkan terhambatnya pemahaman secara tuntas terhadap TI di lingkungan SDM pendidikan kita.
Ibrahim (1988:121) mengatakan bahwa hambatan sosial budaya yang dianggap paling serius ialah pertentangan ideologi tentang perubahan proses pembelajaran. Pendidik cenderung berpikiran bahwa satu-satunya sumber dan media belajar terbaik adalah pendidik dan tak akan pernah dapat digantikan dengan media lain apapun bentuknya. Ditambahkan Ibrahim bahwa hal lainnya yang terkait dengan sosial budaya yang menghambat inovasi ialah kurangnya suasana saling tukar pikiran secara terbuka, perbedaan cultural value, dan kurang harmonisnya hubungan antar SDM yang terlibat.

\section{Kompetensi PTK-PNF terhadap Information Communication and Technology (ICT)}

Salah satu ciri penting pendidik yang profesional ialah mempunyai berbagai keahlian dan pengetahuan dalam menjalankan proses pembelajaran yang efektif. Semua ini dapat dicapai apabila pendidik dapat mengelola kelas dengan efektif yang akan menghasilkan hasil pembelajaran yang efektif pula.

Seorang pendidik harus memiliki kemampuan dalam mengelola aspek-aspek yang berhubungan dengan proses belajar membelajarkan berbasis elearning. Munir dalam Ali, dkk. (2007:1360-1361) menyatakan bahwa dalam pembelajaran yang berbasis TI dan komputer maka pendidik diharapkan memiliki sebagai berikut.

1. Kemampuan pengoperasian dan pemeliharaan hardware. Seorang pendidik perlu mengetahui tentang cara mengoperasikan komputer yang digunakannya dalam kelas, termasuk pengetahuan 
komponen-komponen penting dalam sebuah komputer serta fungsi-fungsinya. Seorang pendidik juga perlu mempunyai pengetahuan tentang troubleshooting dan membuat minor repair.

2. Pengetahuan tentang pemilihan software pendidikan. Setiap hari semakin banyak software pendidikan yang ada di pasaran. Oleh karena itu, seorang pendidik perlu mempunyai pengetahuan tentang pemilihan software yang sesuai untuk membantu proses pembelajarannya.

3. Integrasi pembelajaran dan pembelajaran melalui komputer dalam kurikulum. Pembelajaran melalui komputer memiliki banyak opsi pembelajaran seperti pemrograman, penyelesaian masalah, tutorial, dan game. Seorang pendidik perlu mengetahui bagaimana meletakkan opsi tersebut dalam pembelajaran pada khususnya dan kurikulum pada umumnya.

4. Teknik-teknik pembelajaran menggunakan komputer. Seseorang pendidik perlu mengetahui cara mengendalikan proses pembelajaran dan pembelajaran dengan menggunakan komputer dan software yang digunakan. Seseorang pendidik perlu memahami perbedaan dalam peranan dalam kelas yang menggunakan komputer dibandingkan dengan kelas konvensional. Dalam kelas yang menggunakan komputer, pendidik lebih berperan dalam pengelolaan, supporting agen, dan membantu (facilitate) peserta didik selama komputer digunakan dalam pembelajaran. Seorang pendidik perlu senantiasa memantau aktivitas-aktivitas peserta didik untuk memastikan semua berjalan sesuai dengan rancangan sehingga tujuan pembelajaran tercapai. Seorang pendidik perlu membantu peserta didik selama menjalankan aktivitasnya.

5. Pengetahuan tentang fungsi bantuan pembelajaran (instructional support functions) yang disediakan oleh komputer. Seorang pendidik perlu mengetahui bagaimana komputer dapat membantunya dalam pembelajaran di kelas. Sebagai contoh, pendidik perlu menghasilkan alat bantu membelajarkan sendiri dengan menggunakan software komputer dan menggunakan kemudahan wordprocessing.

6. Peka dengan teknologi terkini. Seorang pendidik harus peka dengan perkembangan teknologi terkini dan produk-produk terbaru di pasaran. Termasuk juga mengikuti workshop-workshop pembelajaran yang dianjurkan di berbagai peringkat (sekolah, kecamatan, kabupaten atau kota, dan provinsi).

Unsur-unsur yang Terlibat untuk Menerapkan TI dalam PNF

1. Ketua pengelola satuan PNF

Agar desentralisasi dan otonomi pendidikan ber- hasil dengan baik, kepemimpinan perlu diberdayakan. Pemberdayaan berarti peningkatan kemampuan secara fungsional sehingga ketua pengelola satuan PNF mampu berperan sesuai dengan tugas, wewenang, dan tanggung jawabnya. Dengan proses dan program pemberdayaan, pengelola akhirnya harus memiliki kinerja yang profesional dan fungsional serta bertindak sebagai manajer dan pemimpin yang efektif.

Sebagai manajer yang baik, ketua pengelola harus mampu mengatur agar semua potensi sekolah dapat berfungsi secara optimal dalam mendukung tercapainya tujuan sekolah. Hal ini dapat dilakukan jika ketua pengelola mampu melakukan fungsi-fungsi manajemen dengan baik yang meliputi: (1) perencanaan, (2) pengorganisasian, (3) pengarahan, dan (4) pengawasan.

Dari segi kepemimpinan, seorang ketua pengelola mungkin perlu mengadopsi gaya kepemimpinan transformasional dalam PNF agar semua potensi yang ada di satuan PNF dapat berfungsi secara optimal. Kepemimpinaan transformasional dapat didefinisikan sebagai gaya kepemimpinan yang mengutamakan pemberian kesempatan dan atau mendorong semua unsur yang ada dalam PNF untuk bekerja atas dasar sistem nilai (values system) yang luhur sehingga semua unsur yang ada di sekolah (pendidik, peserta didik, pengelola, orang tua, dan masyarakat) bersedia, tanpa paksaan, berpartisipasi secara optimal dalam mencapai tujuan ideal satuan PNF. Menurut Luthans (1995:358) ciri seorang yang telah berhasil menerapkan gaya kepemimpinan transformasional adalah sebagai berikut.

a. Mengidentifikasikan dirinya sebagai agen perubahan (pembaruan).

b. Memiliki sifat pemberani.

c. Mempercayai orang lain.

d. Bertindak atas dasar sistem nilai, bukan atas dasar kepentingan individu atau atas dasar kepentingan dan desakan kroninya.

e. Meningkatkan kemampuannya secara terusmenerus sepanjang hayat.

f. Memiliki kemampuan untuk menghadapi situasi yang rumit, tidak jelas, dan tidak menentu.

g. Memiliki visi ke depan.

Slamet (2006) menguraikan 17 ciri ketua pengelola satuan PNF yang tangguh. Ketujuhbelas ciri tersebut memiliki:

a. visi, misi, dan strategi;

b. kemampuan mengkoordinasikan dan menyerasikan sumber daya;

c. kemampuan mengambil keputusan;

d. toleransi terhadap perbedaan pada setiap orang; 
e. memobilisasi sumber daya;

f. memerangi musuh-musuh satuan PNF;

g. menggunakan sistem sebagai cara berpikir dan mengelola;

h. menggunakan input manajemen;

i. menjalankan perannya yang berdimensi banyak seperti manajer, pemimpin, dan pendidikan;

j. melaksanakan dimensi-dimensi tugas, proses, lingkungan, dan keterampilan personal;

k. menjalankan gejala empat serangkai, yaitu merumuskan sasaran, memilih fungsi-fungsi yang diperlukan untuk mencapai sasaran, melakukan analisis Strength, Weakness, Opportunity, and Threat (SWOT) dan mengupayakan langkah-langkah untuk meniadakan persoalan;

I. menggalang teamwork yang cerdas dan kompak;

m. mendorong kegiatan-kegiatan kreatif;

n. menciptakan sekolah belajar;

o. menerapkan manajemen berbasis satuan PNF;

p. memusatkan perhatian pada pengelolaan proses belajar mengajar; dan

q. memberdayakan satuan PNF.

Ketua pengelola satuan PNF mempunyai tugas antara lain: (1) menjamin tersedianya dokumen kurikulum; (2) membantu dan memberikan nasihat kepada pendidik dan anggota pengelola dalam memahami kurikulum; (3) mengatur jadwal pertemuan pendidik, tenaga administrasi, dan orang tua; (4) menjalin hubungan dengan cabang dinas kecamatan, dinas pendidikan kabupaten atau kota, dinas pendidikan provinsi, dan perguruan tinggi dan lembaga terkait dalam pelaksanaan kurikulum dan pengabdian masyarakat; serta (5) menyusun laporan evaluasi perencanaan dan pelaksanaan kurikulum di satuan PNF juga menyampaikannya para pihak yang terkait.

Rencana satuan PNF harus disusun secara menyeluruh mencakup seluruh bidang garapan, yaitu:

a. perencanaan bidang terhadap warga belajar,

b. perencanaan bidang personel atau tenaga kependidikan,

c. perencanaan bidang sarana pendidikan,

d. perencanaan bidang ketatausahaan satuan PNF,

e. perencanaan bidang anggaran PNF,

f. perencanaan pembinaan organisasi satuan PNF,

g. perencanaan hubungan kemasyarakatan pendidikan,

h. menyusun jadwal pelaksanaan kegiatan,

i. memimpin rapat dan membuat notulen rapat,

j. membuat statistik, dan

k. menyusun laporan bulanan.

2. Peranan PTK-PNF terhadap penerapan TI dalam pendidikan
Dalam implementasi kurikulum, pendidik dapat dikatakan sebagai ujung tombak keberhasilan termasuk juga dalam penerapan TI pada semua bidang pembelajaran selain sebagai bidang studi atau mata pelajaran tersendiri. Pendidik TI bekerja sama dengan semua eleman terkait untuk mengintegrasikan TI itu sendiri dalam pembelajaran setiap bidang studi sehingga pengetahuan warga belajar khusus TI lebih dapat didayagunakan.

Dengan usaha pendidik, warga belajar dapat bersemangat belajar lebih keras untuk mencapai tujuan pembelajaran yang bersumber dari tujuan kurikulum. Semua sangat tergantung pada keahlian dan keterampilan pendidik dalam kaitannya dengan pembelajaran, bahan yang dimiliki, dan latihan kependidikan yang alami. Berbagai hal yang perlu dikuasai PTK-PNF, antara lain:

a. PTK-PNF harus mampu memahami diri warga belajar yang menjadi tanggung jawabnya, misalnya tingkat pertumbuhan dan perkembangan anak, keadaan emosi,dan kondisi lingkungan sosiokulturalnya;

b. PTK-PNF harus menguasai kemampuan profesional yang memadai;

c. PTK-PNF harus mampu perlu berperan aktif dalam pengembangan kurikulum PNF;

d. PTK-PNF harus mampu menguasai kurikulum PNF;

e. PTK-PNF harus memiliki dan mampu merefleksikan konsep dirinya ke arah pemberdayaan dan pengembangan masyarakat; serta

f. PTK-PNF mampu memupuk hubungan yang harmonis dengan warga belajar, dan berbagai stakeholder terkait.

Murphy, dkk. (2001:64) mengemukakan untuk meningkatkan kemampuan berkomunikasi melalui TI, upaya yang perlu dilakukan adalah sebagai berikut.

a. Mengaktifkan perserta didik untuk berdebat melalui email.

b. Kerja sama merumuskan proses pemecahan masalah.

c. Mengemukakan pendapat melalui email.

d. Merumuskan hasil perdebatan melalui email dan mendiskusikan proses pengembangannya.

e. Merumuskan pemecahan masalah dari induktif ke deduktif.

Untuk dapat melaksanakan semua itu maka tugas PTK-PNF harus diatur secara administratif untuk menjamin kelancaran pelaksanaan kurikulum dalam dalam proses pembelajaran. Tugas yang harus diatur tersebut antara lain pembagian tugas membelajarkan, membina ekstrakurikuler, dan membimbing belajar. Pembagian tugas tersebut dilakukan melalui musyawarah yang dipimpin ketua 
pengelola satuan PNF dan mempertimbangkan berbagai hal. Adapun Tugas PTK-PNF sendiri dalam implementasi lebih berkaitan dengan bidang proses, seperti:

a. menyusun rencana pelaksanaan program atau unit berdasarkan standar isi (BSNP, 2005) yang telah ditentukan sesuai dengan kurikulum yang berlaku;

b. menyusun jadwal pelaksanaan kegiatan atau jadwal pembelajaran;

c. mengisi daftar penilaian kemajuan belajar dan perkembangan warga belajar yang berguna untuk memudahkan ketua pengelola satuan PNF mengontrol kemajuan pembelajaran sebagai satu keseluruhan dan setiap individu; dan

d. pengisian laporan pribadi warga belajar yang berfungsi untuk menghimpun data pribadi seperti keadaan orang tua, tingkat sosial ekonomi, serta kesulitan pribadi.

3. Orang tua warga belajar, komite satuan PNF, dan masyarakat

Untuk mendukung penerapan TI dalam PNF, orang tua warga belajar, dan masyarakat turut serta membantu satuan pendidikan mengadakan fasilitas $\mathrm{TI}$, misalnya dalam bentuk sumbangan untuk perbaikan dan pengadaan sarana prasarana pendidikan. Orang tua berhak menerima laporan kemajuan anaknya secara berkala dari satuan PNF yang berupa rapor. Rapor merupakan sarana komunikasi program atau kegiatan yang dilaksanakan. Orang tua juga dapat berpartisipasi dalam kegiatan di satuan PNF melalui diskusi, lokakarya, seminar, pertemuan orang tua dengan PTK-PNF, pameran satuan PNF, dan mengawasi penyalahgunaan pemanfataan $\mathrm{TI}$ dalam pendidikan. $\mathrm{Di}$ samping itu, ada juga stakeholders, yaitu tokoh masyarakat atau orang yang peduli terhadap TI dalam pendidikan akan memberikan masukan-masukan sebagai bahan pertimbangan perbaikan program pembelajaran.

Mengenai keterlibatan pihak eksternal pada satuan PNF (Wijaya, 2001:35) mengemukakan keterlibatan orang tua, pemerhati pendidikan, stakeholder, dan masyarakat akan mempengaruhi kualitas penerapan TI dalam pendidikan. Pemahaman stakeholder terhadap kondisi sarana dan prasana pendidikan akan mempengaruhi minat dan motivasi mereka dalam pengadaan atau perbaikan fasilitas yang langsung menunjang proses pembelajaran di satuan PNF.

4. Pelayanan kepada warga belajar

Dalam proses pelayanan pembelajaran kepada warga belajar, Abdulhak dalam Ali, dkk. (2007:523) mengatakan pembelajaran pada hakikatnya mempersiapkan peserta didik untuk dapat menampilkan tingkah laku hasil belajar dalam kondisi yang nyata atau untuk memecahkan masalah yang dihadapi dalam kehidupannya. Pembelajaran memerlukan perhatian semua pihak. Di bidang TI pembelajaran, peserta didik tingkat I diberikan pembelajaran program word, tingkat II pembelajaran program excel dan tingkat III program powerpoint, dan pembelajaran berbasis internet.

Untuk memperdalam penggunaan komputer terkait dengan mata pelajaran, peserta didik ditugaskan untuk membuat laporan berupa bahan cerita pada mata pelajaran bahasa Indonesia dan mencari kliping koran untuk semua mata pelajaran. Waktu pembelajaran pada setiap kelas selama 45 menit masih sangat kurang jika dibandingkan dengan minat peserta didik untuk menerapkan TI dalam pembelajaran. Solusi yang penulis ajukan kepada pihak satuan PNF agar mendayagunakan fasilitas TI di luar jam pembelajaran dengan konsekuensi pembayaran yang akan disepakati antara pihak manajemen TI satuan pendidikan dengan orang tua warga belajar yang dibayar setiap semester. 5. Pengelolaan proses belajar membelajarkan yang terintegrasi TI

Praktik pembelajaran TI memerlukan perhatian semua pihak termasuk kajian disiplin ilmu. Proses belajar membelajarkan merupakan kegiatan utama. Satuan PNF diberi kebebasan memilih strategi, metode, dan teknik-teknik pembelajaran serta pembelajaran yang paling efektif sesuai dengan karakteristik mata pelajaran, karakteristik warga belajar, karakteristik pendidik, dan kondisi nyata sumber daya yang tersedia (Abdulhak dalam Ali, dkk., 2007:523).

Secara umum, strategi metode atau teknik pembelajaran yang berpusat pada siswa (studentcentered) lebih mampu memberdayakan pembelajaran siswa. Wijaya (2001:36) menyatakan tujuan pembuatan produk TI dalam pendidikan ialah menumbuhkan kesenangan untuk mencapai tujuan pembelajaran dan produk teknologi dibuat untuk tujuan tertentu. Pernyataan di atas mengemukakan perkembangan teknologi yang relatif jauh lebih cepat dibandingkan dengan dunia pendidikan, walaupun ia juga merupakan hasil dari pendidikan.

Berkaitan dengan hal tersebut Carol dalam Wijaya, et al. (2001) mengemukakan derajat keberhasilan warga belajar sebagai berikut: (1) penggunaan waktu belajar efektif secara utuh; (2) ketekunan mempelajari pelajaran; (3) bakat warga belajar mempelajari pelajaran itu; (4) kemampuan warga belajar mengolah bahan pelajaran; (5) kualitas pembelajaran yang disampaikan PTK-PNF. 
Peningkatan Peran PTK-PNF...

Kemampuan mengingat informasi sangat dipengaruhi oleh fungsi otak kiri dan otak kanan. Hasil penelitian
Roger Sperry dalam Wijaya (2001:107) membedakan dua fungsi belahan otak kiri dan belahan otak kanan.

Tabel Deskripsi Fungsi Otak Kiri dan Otak Kanan

\begin{tabular}{|l|l|}
\hline \multicolumn{1}{|c|}{ Belahan Otak Kiri } & \multicolumn{1}{c|}{ Belahan Otak Kanan } \\
\hline $\begin{array}{l}\text { Memperhatikan pada komponen } \\
\text { bagian-bagian dan mendeteksi } \\
\text { ciri-ciri. }\end{array}$ & $\begin{array}{l}\text { Memperhatikan pada keseluruhan dan } \\
\text { keterpaduan, mengintegrasikan bagian-bagian } \\
\text { dalam keseluruhan. }\end{array}$ \\
\hline Bersifat analitis. & $\begin{array}{l}\text { Mencari hubungan komplementer satu sama } \\
\text { lain, mengkonstruksikan, dan mempolakannya. }\end{array}$ \\
\hline $\begin{array}{l}\text { Memprosesnya berurutan dan } \\
\text { berseri. }\end{array}$ & Memprosesnya secara simultan dan paralel. \\
\hline $\begin{array}{l}\text { Bersifat temporer. } \\
\text { Di bidang verbal bersifat } \\
\text { menyandikan pembicaraan dan } \\
\text { angka-angka dalam matematika } \\
\text { dan musik. }\end{array}$ & Di bidang verbal bersifat spasial dan musikal. \\
\hline
\end{tabular}

\section{Pengelolaan fasilitas TI}

Dalam pengelolaan falisiltas $\mathrm{TI}$, Somek dan Davis (1997:21) mengemukakan "classrooms are not ideal learning environments; they are working compromises in mass education system". Artinya, pengelolaan fasilitas teknologi secara ideal memperhatikan lingkungan pembelajaran. Pengelolaan fasilitas dilakukan oleh manajemen bagian TI pendidikan yang dibawahi langsung oleh ketua pengelola satuan PNF yang berkoordinasi langsung dengan Pusat Pengembangan Teknologi Pendidikan Nasional (Pustekom Diknas). Pengelolaan meliputi pengadaan, pemeliharaan dan perbaikan, serta pengembangan peralatan itu sendiri. Hal ini didasarkan oleh kenyataan bahwa satuan pendidikanlah yang paling mengetahui kebutuhan fasilitas, baik kecukupan, kesesuaian maupun kemutakhirannya.

7. Kerja sama dengan pakar pendidikan dan ahli TI

Dalam proses implementasi pembelajaran berbasis $\mathrm{TI}$, dewan para pakar ilmu pendidikan, PTKPNF, dan ahli TI sangatlah penting. Tugas dewan pakar, antara lain:

a. sebagai pembina atau sponsor implementasi pembelajaran yang berbasis $\mathrm{TI}$,

b. mengajukan perencanaan dan pengembangan teknologi berbasis TI,

c. melakukan penelitian bidang pengembangan pembelajaran yang berbasis $\mathrm{TI}$,

d. menyusun buku sumber yang dibutuhkan sesuai dengan pembelajaran yang berbasis $\mathrm{TI}$, dan e. memberikan pelatihan dan penataran kepada PTK-PNF tentang pembelajaran yang berbasis $\mathrm{TI}$.

8. Internet memfasilitasi pendidikan

Kemajuan TI berdampak pada segala aspek kehidupan terutama pada dunia pendidikan. Dampak positif dalam dunia pendidikan adalah memungkinkan pembelajaran yang sangat cepat dari warga belajar untuk dapat mengakses beragam informasi dari seluruh belahan dunia. Gill (2003:126) menyatakan TI diorganisasikan sebagai saluran telekomunikasi yang dapat mengembangkan kemampuan warga belajar dalam mempercepat pencapaian tujuan pendidikan. Oleh karena itu, pertukaran informasi dan kerja sama antarlembaga pendidikan dari berbagai tempat sangat memungkinkan tanpa harus hadir secara fisik. Sebagaimana Benson dalam Gill (2003:213) mengatakan bahwa sistem informasi pendidikan merupakan bagian dari kurikulum metakognisi pendidikan.

Oetomo (2007:6) mengemukakan kaitan internet dengan dunia pendidikan berbagai peluang dapat diciptakan di mana sejak internet difungsikan tahun 1990an denyut nadi pendidikan seakan tak pernah berhenti. Sekolah virtual (warnet) dapat dibangun dan dibuka selama 24 jam untuk melayani konsumen termasuk peserta didik. Manfaat yang dapat diperoleh dunia pendidikan dapat memperoleh perluasan jaringan mitra kerja, baik dengan institusi dalam maupun luar negeri serta pengendalian biaya, khususnya pengurangan biaya pembangunan sarana fisik. E-learning mengefektifkan hubungan antara 
peserta didik dengan pendidik tanpa terikat tempat dan waktu.

Dibalik beragam manfaatnya, internet juga mempunyai dampak negatif terhadap kemanan dan kerahasiaan dokumen baik dari segi bisnis maupun dari segi budaya. Contoh dalam dunia perbankan ketika ecommerce mulai marak, pencurian kartu kredit meningkat untuk melakukan transaksi di internet sedangkan dampak negatif pada bidang budaya dan moral, seorang pengakses internet dengan bebas mendapatkan hal-hal yang merusak moral berupa gambar-gambar pornografi, pergaulan bebas, dan budaya-budaya yang merusak tatanan kehidupan beragama serta bermasyarakat (Oetomo, 2007:359).

\section{KESIMPULAN}

1. Masalah implementasi pembelajaran berbasis TI di satuan PNF dapat dipecahkan dengan melakukan kerja sama antara sekolah (dalam hal ini ketua pengelola dan pendidikan pada satuan PNF), komite satuan PNF, orang tua warga belajar, pemerhati dan ahli TI, pemuka agama, serta tokoh masyarakat secara intens. Keterlibatan komite satuan PNF dan orang tua warga belajar bertujuan untuk membantu pengadaan dan perawatan fasilitas TI berupa sumbangan wajib yang telah disepakati bersama. Keterlibatan ahli teknologi infomasi bertujuan untuk memperoleh gambaran impelementasi TI dan keterlibatan ahli pendidikan (PNF) bertujuan untuk memperoleh gambaran penerapan teori-teori pendidikan melalui jasa TI. Adapun keterlibatan tokoh agama dan tokoh masyarakat bertujuan untuk membentengi pengguna internet terutama warga belajar dari dampak negatif yang bersumber dari internet.

2. Pembelajaran berbasis TI dapat membuka wawasan warga belajar dalam memperoleh sumber-sumber materi pembelajaran yang berkaitan dengan mata pelajaran yang telah tercantum dalam kurikulum maupun yang tidak tercantum dalam kurikulum.

3. Untuk menjaga kelanggengan operasional TI diperlukan pendayagunaan fasilitas TI menjadi menjadi warnet satuan PNF yang dapat dikomersilkan sehingga dapat membiayai pembayaran abodemen dan pulsa internet.

4. Dalam pembelajaran berbasis TI warga belajar perlu dibekali dengan pesan-pesan moral sehingga tidak terjerumus pada dampak negatif penggunaan $\mathrm{TI}$ (internet).

\section{DAFTAR PUSTAKA}

Ali,M., Ibrahim, R., Sukmadinata, N.S., \& Sudjana, D. (2007). IImu dan aplikasi pendidikan. Bandung: Pedagogian Press.

Budiningsih. (2005). Belajar dan pembelajaran. Jakarta: Rineka Cipta.

Depdiknas. (2005). Standar nasional pendidikan. Jakarta: BSNP.

Gill, Mc. (2003). Current issues in IT education. London: IRM Press.

Murphy, dkk. (2001). On-line learning and teaching with technology (case studies, experience and practice). London: Kogan Page Limited.

Oetomo, dkk. (2007). Pengantar TI (konsep dan aplikasi). Yogyakarta: Andi Ofset.
PH. Slamat. (2006). Manajemen berbasis sekolah. Yogyakarta: CD, off-line.

Somek \& Davis. (1997). Using information technology (effectively in teaching and learning, studies ind pre-service and in-service teacher education). USA and Canada: Great Britain by Redwood Books, Trowbridge, Wiltshire.

Sudjana. (2003). Teknologi pembelajaran. Bandung: Sinar Baru Algensindo.

Wahid. (2007). TI pendidikan. Yogyakarta: Ardana Media.

Wijaya, et al. (2001). Remedial pendidikan (sarana pengembangan sumber daya manusia). Bandung: Remaja Rosdakarya. 